\title{
Factors influencing intellectual capital disclosure by Portuguese companies
}

\author{
Ana Lúcia Ferreira \\ ColepCCL, Portugal \\ e-mail: anapferreira@portugalmail.pt \\ Manuel Castelo Branco (Corresponding author) \\ Faculty of Economics of University of Porto / OBEGEF, Portugal \\ e-mail: mcbranco@fep.up.pt \\ José António Moreira \\ Faculty of Economics of University of Porto / CEF.UP / OBEGEF, Portugal \\ e-mail: jantonio@fep.up.pt
}

Received: December 08, 2012 Accepted: December 27, 2012 DOI: 10.5296/ijafr.v2i2.2844

\begin{abstract}
This study analyzes annual reports as media of intellectual capital disclosure (ICD) by Portuguese listed companies using a costs/benefits theoretical framework. According to this framework companies have an incentive to disclose voluntary information when the benefits to be derived from additional disclosure are perceived to outweigh the associated costs. Regression analysis is used to analyze some factors which influence ICD. The findings reported in this study are consistent with those obtained in previous studies. Information on external capital is the type of information on IC that more companies disclose in their annual reports. The kind of intellectual information that more companies disclose in their annual reports pertains to management processes, business collaborations, brands, and the profile of workers. Results also show that size and type of auditor are significant in explaining ICD, whereas leverage, profitability, ownership concentration, and intellectual capital level are not.
\end{abstract} Keywords: Annual reports, Intellectual capital disclosure, Portugal. 


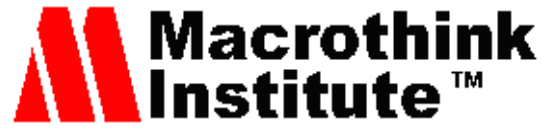

International Journal of Accounting and Financial Reporting

ISSN 2162-3082

2012, Vol. 2, No. 2

\section{Introduction}

Advanced economies are shifting towards a knowledge-based economy in which companies' competitiveness and sustainability are increasingly dependent of knowledge based resources. This calls for recognition of new resources, intellectual capital (IC) resources, such as knowledge workers, corporate culture and business strategies, that have not previously been included in corporate financial statements (Rashid et al., 2012). Given the lack of adequate accounting processes for measuring and reporting these resources, corporate managers have recently begun to voluntarily disclose information pertaining to them and how they contribute to the firms' creation of value (García-Meca and Martínez, 2005).

Although the term IC is now widely used among regulators, professional bodies and academics, a precise and agreed definition of IC does not yet exists (Beattie and Thomson, 2007). In the wake of García-Meca and Martínez (2005), IC is understood in this study as knowledge, intellectual property, or experience that can be put to use to create wealth.

The vast majority of research on intellectual capital disclosure (ICD) has been conducted with reference to the annual reports. Several authors point out that the annual report is deemed as the most important communication device used by firms to convey information to their various stakeholders (see, for example, Guthrie and Petty, 2000; Abeysekera and Guthrie, 2005; Bozzolan et al., 2003; Oliveira et al., 2006; Williams, 2001). In our study, we also concentrate on annual reports as the medium of communication. The fact that they are statutory documents, required to be produced on an annual basis by all companies, facilitates the making of comparisons (Branco et al., 2011). Additionally, in countries with low disclosure environments annual reports are still the most important document used by investors to assess corporate transparency (Souissi and Khlif, 2012). Portugal is such a country.

The purpose of this study is to understand ICD in annual reports by developing a series of testable hypotheses. The strategy adopted is one of examining a sample of companies and using proxies for explanatory factors related to company characteristics, like size, financial performance, leverage, or industry affiliation. The nature of ICD in annual reports by a sample of companies listed on the Portuguese Stock Exchange (Euronext - Lisbon) is analysed. Using content analysis, ICD is classified in terms of theme (internal capital, external capital, and human capital).

The empirical analysis in this paper is based on a sample of Portuguese listed companies mainly because there is still an issue as to whether companies in less developed countries, like Portugal, should be expected to behave differently than companies in more developed countries (Branco et al., 2010). Additional and stronger evidence to enlighten the debate is required.

Branco and Rodrigues (2008) suggest that factors which influence social responsibility disclosure practices of Portuguese listed companies are not significantly different from those influencing similar practices from companies in more developed countries. They argue that the similitude in the way in which "... disclosure strategies seem to be determined, irrespective of a given country's socio-cultural environment, is an illustration of the strong 


\section{Mll Macrothink}

International Journal of Accounting and Financial Reporting ISSN 2162-3082 2012, Vol. 2, No. 2

impact of globalized stock markets on fostering convergence in corporate practices" (Cormier and Magnan, 2003, p. 58). One of the purposes of this study is to establish if these arguments can be extended to the case of ICD, as has already been suggested by other studies using very small samples (Branco et al., 2010; Branco et al., 2011).

According to Abeysekera and Guthrie (2005), the disappearance of geographic barriers, decreasing transaction costs, and more freely available capital are affecting companies around the world, including those located in less developed countries. Given that companies in the developed countries are either high tech companies or knowledge intensive or a combination of both, whereas companies in less developed countries are less knowledge intensive and frequently labour intensive, Rashid (2010) argues that it is not appropriate to generalize the results of studies on ICD in developed countries to less developed countries. This paper contributes to understanding of ICD by companies in a moderately developed country setting, with specific socio-economic characteristics.

The concept of IC and hence ICD are not as well-developed in Portugal as in more developed countries. Few studies on ICD by Portuguese companies have been published in international journals. We believe that increased appreciation of the levels of ICD is likely to encourage greater debate over IC management and the reporting thereof. On the other hand, there is value added in exploring ICD in a peripheral country context, and evaluate the extent to which this type of disclosure has matured in these types of countries in comparison to what happens in more developed countries.

The results obtained confirm the trends in disclosure documented in Oliveira et al. (2006). Portuguese companies voluntarily disclose information on intellectual capital in their annual reports. The kind of intellectual capital information that more companies disclose in their annual reports pertains to external capital.

In spite of the particular characteristics of Portugal, the results of this study suggest that factors which ICD practices of Portuguese listed companies are not significantly different from those influencing similar practices from companies in more developed countries. This much has been hinted by Branco et al. (2010) and Branco et al. (2011) in exploratory studies with very small samples. We view these findings as an illustration of the impact of globalized capital markets on fostering convergence in corporate practices (Branco and Rodrigues, 2008).

The remainder of the paper is organized as follows. Section 2 develops the theoretical framework. Section 3 presents the hypotheses developed. Section 4 describes the methodology and section 5 analyzes the empirical results. Finally, section 6 presents the summary and concluding remarks.

\section{Theory Development}

The decision to disclose information on IC is analyzed in this study using a costs/benefits framework. This type of theoretical framework has been used to analyse different types of voluntary disclosure, ranging from financial and non-financial voluntary disclosure in the annual reports of French listed companies (Depoers, 2000) to the analysis of environmental 


\section{Mll Macrothink}

International Journal of Accounting and Financial Reporting

ISSN 2162-3082

2012, Vol. 2, No. 2

disclosure in the annual reports and environmental reports of non-financial French listed companies (Cormier and Magnan, 2003). ICD practices have also been studied through this lens of analysis (Brüggen et al., 2009; García-Meca et al., 2005; Vergauwen and Alem, 2005).

This framework suggests that corporate managers weight the benefits and the costs of additional disclosure and have an incentive to disclose voluntary information when the first are perceived to outweigh the latter.

The main benefits associated to voluntary disclosure derive from reductions in information asymmetry (Brüggen et al., 2009; García-Meca et al., 2005; Vergauwen and Alem, 2005). Given that managers usually have access to information that investors do not (information asymmetry), in the absence of credible information about the company investors will assume the worst and will bid down its stock price or require an interest rate premium on debt. Alternatively, if investors consider the benefits from information gathering to outweigh the costs, they may seek and collect more information from alternative sources. By disclosing credible information, a company allows investors to reduce such data collection and analysis costs thereby making the company shares more attractive (Lang and Lundholm, 1993). Benefits derived from this strategy are related to the reduction in cost of capital, an increase in stock liquidity and the enhancement of interest by investors (Healy et al., 1999). Thus, there are benefits from additional disclosure related to a reduction in information asymmetry and in overall information gathering costs to be assumed by investors.

A recent meta-analytic review on the relationship between voluntary disclosure and cost of equity capital by Souissi and Khlif (2012) reports a very interesting finding for our study. Their analysis provides support for a significant and negative association between voluntary disclosure and cost of equity capital only for low disclosure environments, such as China, Brazil, France, Switzerland, Germany, continental Europe and some emergent markets, where annual reports are still the most important document used by investors to assess corporate transparency. They attribute this result to the relatively low level of investor protection laws prevailing in such environments when compared to that prevailing in countries such as the USA, the UK, Canada and Australia.

Good assessments of a firm's future wealth creation capabilities, leading to more precise valuations of the firm, can only be made by stakeholders who are well informed (Li et al., 2007). Voluntary disclosure also leads to increases in analyst following and promotes greater liquidity in the stock market (Healy and Palepu, 1993; Healy et al., 1999). Botosan (1997) documents a negative association between the cost of equity capital and voluntary disclosure level for firms with a low analyst following. Sengupta (1998) suggests that benefits arising from disclosure quality are not limited to the cost of equity capital, and also include a lower cost of issuing debt.

On the other hand, there are direct costs of disclosure associated to the preparation, audit and publication of reports (García-Meca et al., 2005; Vergauwen and Alem, 2005) as well as opportunity costs of employees involved in the disclosure process (Schiemann et al., 2011). Other possible costs include those pertaining to proprietary information that may be contained in voluntary disclosure and may be used by stakeholders (such as employees, labor 


\section{Mll Macrothink}

International Journal of Accounting and Financial Reporting

ISSN 2162-3082

2012, Vol. 2, No. 2

unions, competitors, and regulators), to the disadvantage of the disclosing firm (Brüggen et al., 2009; García-Meca et al., 2005; Schiemann et al., 2011; Vergauwen and Alem, 2005). Verrecchia (1983) suggested that a firm voluntarily discloses information only if the proprietary costs associated with the disclosure are outweighed by the perceived benefits.

\section{Hypotheses development}

\subsection{Company size}

There is abundant evidence suggesting a positive relationship between the size of a company and its ICD (see, for example, Bozzolan et al., 2003; Brügen et al., 2009; Guthrie et al., 2006; García-Meca et al., 2005; Oliveira et al., 2006; Ousama et al., 2012). There are some relatively straightforward reasons explaining why large companies are considered to be more prone to disclose IC information (Ousama et al., 2012): 1) large companies have the resources to disclose more information; 2) larger companies tend to have better internal management information systems as a result of the variety of their activities, thus being able to disclose more information.

In addition to these aspects, Gárcia-Meca et al. (2005) refer the higher visibility and exposure to political attacks, in the form of pressure to exercise social responsibility or greater regulation in the form of price controls or higher corporate taxes, of larger companies. The larger variety and extent of disclosure by larger companies is related to their higher sensitivity to political costs. Furthermore, the proprietary costs associated to competitive disadvantages of additional disclosure (Verrecchia, 1983) decrease as company size increases.

H1: There will be a positive relationship between size and ICD.

\subsection{Ownership concentration}

The potential for agency conflicts is higher in firms with lower ownership concentration due to divergence of interests between contracting parties. These companies have a larger number of shareholders who are not directly involved in the management of the company and, consequently, the agency costs due to information asymmetry between owners and managers are higher (Prencipe, 2004). These companies are more likely to experience pressure from shareholders for greater disclosure to reduce agency costs and information asymmetry. Companies with lower ownership concentration may provide additional information to signal that the managers are acting in the best interests of the principals. In contrast, companies with higher ownership concentration are expected to have lower costs due to information asymmetry between management and owners who typically have access to the information they need (Li et al., 2008).

$\mathrm{H} 2$ : There will be a negative relationship between ownership concentration and ICD.

\subsection{Leverage}

Because firms with higher leverage levels incur more agency costs (potential wealth transfers from debt-holders to shareholders and managers), they seek to reduce these costs and 


\section{Mll Macrothink}

International Journal of Accounting and Financial Reporting

ISSN 2162-3082

2012, Vol. 2, No. 2

information asymmetries by disclosing more information to satisfy the needs of creditors for information (Prencipe 2004). Voluntary disclosure is especially important in the knowledge based company where substantial amounts of money are invested in intangible assets, which are not fully recognized on the financial statements (Brügen et al., 2009).

H3: There will be a positive relationship between leverage and ICD.

\subsection{Profitability}

Khlif and Souissi (2010) contend that a positive relationship between disclosure and profitability can be justified on the basis of two theoretical arguments. First, as suggested by agency theory, higher performance makes it easier for managers to convince shareholders about their superior managerial abilities. They are likely to use voluntary disclosure to obtain higher degrees of confidence from investors, which may be reflected in higher compensation. Second, profitable firms have incentives to disclose more information in order to screen themselves from less profitable firms. In addition, managers of profitable companies have incentives to use information in order to obtain personal advantages such as continuance of their positions and compensation arrangements.

On the other hand, the adverse attention that high-profits draw may lead to political costs (Watts and Zimmerman, 1978). Profitable companies are more likely to use voluntary disclosures to reduce political costs. Another important aspect is that profitability may be the result of continuous investment in intellectual capital and companies are likely to engage in ICD to signal the significance of such investment (Li et al., 2008).

H4: There will be a positive relationship between profitability and ICD.

\subsection{Industry affiliation}

Ousama et al. (2012) suggest that companies belonging to the same industry have incentives to present similar levels of ICD, different from those of other industries, related to the wish of proving their compliance with the best practices of the industry. They contend that when a company in an industry exhibits lower levels of disclosure when compared to other companies in the same industry, this may be considered as a signal that the company is intentionally hiding information due to bad news (ibid.).

Proprietary costs vary across industries (Verrechia, 1983). Companies belonging to the same industry have incentives to disclose more, or less information than companies belonging to another industry. For example, because of the nature of their products and their research and development, some industrial sectors are likely to be more sensitive about disclosures to competitors and the public than companies in other industries. Additionally, companies in the same industry are interested in having the same level of disclosure in order to avoid negative appreciation by the market (competitive pressures).

Many studies suggest that firms from technology-based or knowledge-intensive industries will engage in more ICD (Bozzolan et al., 2003; Petty and Cuganesan, 2005; Bozzolan et al., 
2006; Oliveira et al., 2006; Whiting and Woodcock, 2011). However, empirical evidence is not conclusive. Some authors find a positive association between industrial affiliation and ICD (see, for example, Bozzolan et al., 2003; Brügen et al., 2009; Guthrie et al., 2006; García-Meca et al., 2005; Oliveira et al., 2006; Petty and Cuganesan, 2005; Whiting and Woodcock, 2011), while others find none (García-Meca et al., 2005; García-Meca and Martínez, 2005). This could be due to the lack of representativeness in sampling at the sector level (Li et al., 2007). In view of the existence of these results, the association between this variable and ICD is tested without making any a priori assumption about the sign of such association.

H5: ICD will be associated with the company's industry.

\subsection{Type of auditor}

Auditing is a way of reducing agency costs (Watts and Zimmerman, 1979) and enhancing the credibility of the information disclosed. Extant literature suggests that Big $\mathrm{N}$ audit firms provide higher quality audits relative to non-Big $\mathrm{N}$ audit firms and that this is valued by equity markets (Azizkhani et al., 2010). Companies facing high agency costs will contract high quality auditing companies. The Big 4 audit firms are considered to have more resources than other firms and to arguably provide a higher quality audit (Hakim, 2010). The independence enjoyed by large audit firms enables them to influence corporate financial reports to satisfy the external users' needs for reports, since their value as auditors, in part, depends on how users of annual reports perceive the auditors' report (Barako, 2006).

H6: Companies appointing Big 4 audit firms will have a greater extent of ICD.

\subsection{Level of intellectual capital}

Good companies have incentives to signal positive information to the market. They have incentives to disclose more information in order to screen themselves from other companies. Therefore, management in companies with high levels of IC would be motivated to signal to the market positive information about those intangibles (Brennan, 2001; Whiting and Miller, 2008). On the other hand, companies with high-IC performance are also more likely to disclose IC information because they can withstand the scrutiny and action of various stakeholders (Williams, 2001).

H7: There will be a positive relationship between the level of intellectual capital and ICD.

\section{Methods}

\subsection{Empirical model}

To investigate the influence of the selected factors on ICD of the companies in the sample, we estimated the following regression model with an ordinary least squares (OLS) technique:

$$
\mathrm{ICDi}=\beta 0 \mathrm{i}+\beta 1 \mathrm{iSi}+\beta 2 \mathrm{iOCi}+\beta 3 \mathrm{iLevi}+\beta 4 \mathrm{iProfiti}+\beta 5 \mathrm{iHVi}+\beta 6 \mathrm{iTAi}+\sum \beta 7+\mathrm{j} \mathrm{Iji}+\mathrm{ui}
$$


Where, for company i:

Si: size;

OCi: ownership concentration;

Levi: leverage;

Profiti: profitability;

HVi: intellectual capital level;

TAi: Big four vs Non-Big four (i.e. 1 for Big four, 0 otherwise);

Iij: Dummy for sector $\mathrm{j}$; 1 if the company belongs to sector $\mathrm{j}, 0$ otherwise $(\mathrm{j}=1 \ldots 9)$;

ui: error term.

\subsection{Operationalization of variables}

Table 1 provides a summary of the operational definition of variables and their sources, as well as the hypotheses to which they pertain.

Table 1: Operational definitions of variables

\begin{tabular}{|l|l|l|l|}
\hline $\mathbf{H}_{\mathbf{x}}$ & Variable & Operational definitions of variables & Source of information \\
\hline $\mathrm{H}_{1}$ & Company size & Logarithm of the value of firm total assets & Company annual reports \\
\hline $\mathrm{H}_{2}$ & $\begin{array}{l}\text { Ownership } \\
\text { concentration }\end{array}$ & $\begin{array}{l}\text { Ratio of number of outstanding common } \\
\text { shares held by individuals or organizations } \\
\text { classified as substantial shareholders } \\
\text { (those holding more than 2\% of outstanding } \\
\text { shares) to the total number of } \\
\text { outstanding common shares of the firm }\end{array}$ & Company annual reports \\
\hline $\mathrm{H}_{3}$ & Leverage & Ratio of total debt to equity capital & Company annual reports \\
\hline $\mathrm{H}_{4}$ & Profitability & $\begin{array}{l}\text { Ratio of net profit before taxation to total } \\
\text { assets }\end{array}$ & Company annual reports \\
\hline $\mathrm{H}_{5}$ & Industry & $\begin{array}{l}\text { Dummy variables for each of the sectors } \\
\text { sampled }\end{array}$ & $\begin{array}{l}\text { Euronext web } \\
\text { site(www.euronext.com })\end{array}$ \\
\hline $\mathrm{H}_{6}$ & Type of auditor & Dummy variable (1 for Big4, otherwise 0) & Company annual reports \\
\hline $\mathrm{H}_{7}$ & $\begin{array}{l}\text { Level of intellectual } \\
\text { capital }\end{array}$ & Market capitalization / Equity & $\begin{array}{l}\text { Company annual reports; } \\
\text { Euronext } \text { Web site } \\
\text { (www.euronext.com) }\end{array}$ \\
\hline
\end{tabular}

\subsection{Sample}

This study uses a sample of listed companies, as they are more likely to disclose intellectual capital information. In order to be included in the sample for this study, companies had to: 


\section{Macrothink}

International Journal of Accounting and Financial Reporting ISSN 2162-3082 2012, Vol. 2, No. 2

- have its shares listed on the Portuguese Stock Exchange (Euronext - Lisbon) by the end of 2006,

- have the 2006 annual report available for review.

The initial sample included all companies listed on Euronext - Lisbon at 31 December 2006. From the initial 51 listed companies, a final sample of 45 companies was identified. Five companies were excluded because they are not subject to Portuguese law (non-resident companies). One company was excluded because it stopped being listed during 2007 and its annual report was not available.

The Portuguese Securities Market Commission (Comissão do Mercado de Valores Mobiliários - CMVM) web page was used in order to obtain the 2006 annual reports for sample companies. The annual report of one of the companies was not available at the CMVM web page. However, it was available from the company website, and it was collected from this source.

The companies included in the sample are classified according to sectors using the ICB. This classification system comprises the several sectors which are considered in Table 2. Industrials is the sector which presents the largest number of companies (13 companies and around $29 \%$ of the total). Consumer services is the sector which follows in terms of degree of importance (11 companies and about $24 \%$ of the total).

\section{Table 2: Sample companies by sector}

\begin{tabular}{|l|l|l|}
\hline Industry & $\mathbf{N}$ & $\mathbf{\%}$ \\
\hline 0001 Oil \& Gas & 1 & $2 \%$ \\
1000 Basic Materials & 5 & $11 \%$ \\
2000 Industrials & 13 & $29 \%$ \\
3000 Consumer Goods & 3 & $7 \%$ \\
5000 Consumer Services & 11 & $24 \%$ \\
6000 Telecommunications & 2 & $4 \%$ \\
7000 Utilities & 1 & $2 \%$ \\
8000 Financials & 5 & $11 \%$ \\
9000 Technology & 4 & $9 \%$ \\
\hline Total & $\mathbf{4 5}$ & $\mathbf{1 0 0 \%}$ \\
\hline
\end{tabular}

\subsection{Data collection}

This study uses a method that has become a method widely used in the study of ICD, content analysis (Abeysekera and Guthrie, 2005; Bozzolan et al., 2003; Brennan, 2001; Brügen et al., 2009; Guthrie and Petty, 2000; Oliveira et al., 2006; Petty and Cuganesan, 2005; Rashid et al., 2012; Whiting and Woodcock, 2011). Using this method implies classifying the information on IC disclosed by firms into various categories of items that capture the aspects one wants to analyse.

Merely detecting the presence or absence of information is a method that has been used by 


\section{Macrothink}

International Journal of Accounting and Financial Reporting

several authors (see, for example, Guthrie and Petty, 2000; Brennan, 2001; April et al., 2003; Bukh et al., 2005). It is the simplest form of content analysis. Since it precludes measurement of the extent of information disclosed, the data does not reflect the emphasis attached by firms to each information item. Capturingh the extent of disclosure would imply, for exemple, counting words, sentences, or proportion of pages (Unerman, 2000). However, the number of different topics discussed is considered as a reasonable measure of management's willingness to provide information (Bewley and $\mathrm{Li}, 2000$ ).

In this study, the index used is based on the one proposed by Guthrie and Petty (2000), which has been used successfully (in its original format or in a derived format) by various impirical studies (see, for example, April et al., 2003; Bozzolan et al., 2003; Guthrie et al., 2006; Guthrie et al., 2008; Whiting and Miller, 2008). Guthrie and Petty (2000) used a list of 24 subcategories covering the three categories of IC proposed by Sveiby (1997): internal capital, external capital, and human capital.

The analysis of the ICD is made using an equal-weighted index, that is, a scoring system which assigns a point for each ICD theme pertaining to any of the categories considered. Disclosure scores for each company are added and not weighted because it is assumed that each item of disclosure is equally important.

The following disclosure score index was constructed:

$$
\sum_{i=1}^{m_{j}} \frac{d_{i}}{N}
$$

This index expresses the level of disclosure for a company $\mathrm{j}$, where $\mathrm{N}$ is the maximum number of relevant items a company may disclose and di is equal to 1 if the indicator $i$ is disclosed, and 0 otherwise. When the disclosure score index is equal to 0 , it indicates that company $i$ does not disclose any item. Index values equal to $i=1, \ldots$, mj mean that a level of disclosure is provided, and $\mathrm{mj}$ is the maximum number of indicators di disclosed by a company j.

The 2006 annual reports of listed companies were analysed. Only the sections of the annual report where the disclosure of intellectual capital information is voluntary were analysed, namely the chairman's report or letter to the shareholders and the management report.

\section{Results and discussion}

\subsection{Descriptive analysis}

Results show that Portuguese listed companies disclose intellectual capital information. In 2006 all the companies in the sample disclosed at least one of the items of intellectual capital. Companies exhibit a general consciousness about the importance of intellectual capital (Guthrie and Petty, 2000), and thus disclose information on the subject. 
Table 3: ICD areas

\begin{tabular}{|c|c|c|}
\hline Subcategory & Frequency & $\%$ \\
\hline Patents & 0 & $0 \%$ \\
\hline Copyrights & 1 & $2 \%$ \\
\hline Trademarks & 5 & $11 \%$ \\
\hline Intellectual Property & 6 & $4 \%$ \\
\hline Management philosophy & 20 & $44 \%$ \\
\hline Corporate culture & 13 & $29 \%$ \\
\hline Management processes & 37 & $82 \%$ \\
\hline Information systems & 27 & $60 \%$ \\
\hline Networking systems & 17 & $38 \%$ \\
\hline Financial relations & 23 & $51 \%$ \\
\hline Infrastructure Assets & 137 & $51 \%$ \\
\hline Internal capital & 143 & $35 \%$ \\
\hline Brands & 32 & $71 \%$ \\
\hline Customers & 18 & $40 \%$ \\
\hline Customer loyalty & 20 & $44 \%$ \\
\hline Company names & 30 & $67 \%$ \\
\hline Distribution channels & 25 & $56 \%$ \\
\hline Business collaborations & 34 & $76 \%$ \\
\hline Licensing agreements & 31 & $69 \%$ \\
\hline Favourable contracts & 20 & $44 \%$ \\
\hline Franchising agreements & 5 & $11 \%$ \\
\hline Awards & 17 & $38 \%$ \\
\hline External capital & 232 & $52 \%$ \\
\hline Know-how & 13 & $29 \%$ \\
\hline Education & 31 & $69 \%$ \\
\hline Workers & 32 & $71 \%$ \\
\hline Work-related knowledge & 3 & $7 \%$ \\
\hline Work-related competencies & 23 & $51 \%$ \\
\hline Entrepreneurial spirit & 3 & $7 \%$ \\
\hline Human capital & 105 & $39 \%$ \\
\hline Intellectual capital & 480 & $43 \%$ \\
\hline
\end{tabular}

Table 3 presents the frequency of disclosure pertaining to the categories on intellectual capital disclosure defined above. The totals of internal capital, external capital, and human capital represent the number of disclosures made by all the companies in the sample pertaining to all items in the category. Table 3 includes also the disclosure made by companies as a percentage of total possible disclosures.

Results in Table 3 indicate that the kind of intellectual capital information with a higher level of disclosure is external capital information (52\%), followed by human capital information 


\section{Mll Macrothink}

International Journal of Accounting and Financial Reporting ISSN 2162-3082 2012, Vol. 2, No. 2

(39\%) and internal capital information (35\%). The results presented in this study are somewhat similar to those reported by Abeysekera and Guthrie (2005) and Brennan (2001).

The kind of intellectual information that more companies disclose in their annual reports pertains to management processes. Thirty seven companies (82\% percent of the companies) disclose this type of information. Patents and Copyrights are the variables which are least disclosed. Only one company has disclosed information on copyrights and none have disclosed information on patents. These results are consistent with results from Oliveira et al. (2006), and are related to the fact that Portuguese companies are seldom owners of patents.

Regarding external capital, the variables which are disclosed more frequently are business collaborations (34 companies) and brands (32 companies). Information on the profile of workers is the variable of human capital information that more companies disclose (32 companies).

Table 4 offers an insight into whether ICD varies systematically across companies according to their industry.

Table 4: Nature of ICD by sectors

\begin{tabular}{|l|l|l|l|l|}
\hline ICB & $\begin{array}{l}\text { Internal } \\
\text { capital }\end{array}$ & $\begin{array}{l}\text { External } \\
\text { capital }\end{array}$ & $\begin{array}{l}\text { Human } \\
\text { capital }\end{array}$ & $\begin{array}{l}\text { Intellectual } \\
\text { capital }\end{array}$ \\
\hline 0001 Oil \& Gas & $44 \%$ & $80 \%$ & $67 \%$ & $64 \%$ \\
1000 Basic Materials & $31 \%$ & $42 \%$ & $37 \%$ & $37 \%$ \\
2000 Industrials & $29 \%$ & $46 \%$ & $37 \%$ & $38 \%$ \\
3000 Consumer Goods & $22 \%$ & $47 \%$ & $22 \%$ & $32 \%$ \\
5000 Consumer Services & $33 \%$ & $52 \%$ & $35 \%$ & $41 \%$ \\
6000 Telecommunications & $56 \%$ & $55 \%$ & $50 \%$ & $54 \%$ \\
7000 Utilities & $67 \%$ & $80 \%$ & $67 \%$ & $72 \%$ \\
8000 Financials & $60 \%$ & $72 \%$ & $53 \%$ & $63 \%$ \\
9000 Technology & $25 \%$ & $43 \%$ & $33 \%$ & $34 \%$ \\
\hline Total & $\mathbf{3 5 \%}$ & $\mathbf{5 2 \%}$ & $\mathbf{3 9 \%}$ & $\mathbf{4 3 \%}$ \\
\hline
\end{tabular}

The main disclosing sectors were the Utilities (72\%), Oil \& Gas (64\%), and Financials sectors (63\%) (see Table 4). The less disclosing sectors were Consumer Goods (32\%) and Technology (34\%). However, these results are largely influenced by the sample. Utilities and Oil \& Gas are represented by only one company.

What appears more difficult to explain and was not expected are the results for ICD of companies from the technology sector. Companies from this sector are among those with lower levels of disclosure. These results are not consistent with the findings of Williams (2001) and Bukh et al. (2005), who documented that high-tech companies present higher levels of ICD. Reasons for this lower level of disclosure are also related to the sample. One of the companies belonging to this sector has substantially lower levels of disclosure than the other companies in the sector. Thus, the average for the sector is lower than expected. 
Tables 5 and 6 contain the descriptive statistics for the continuous variables (Table 5) and the categorical independent variables (Table 6) defined above.

Table 5: Summary descriptive statistics of continuous variables

\begin{tabular}{|l|r|r|r|r|r|r|}
\hline $\begin{array}{l}\text { Descriptive } \\
\text { statistics }\end{array}$ & ICD & \multicolumn{1}{l|}{ Size } & $\begin{array}{l}\text { Ownership } \\
\text { concentration }\end{array}$ & Leverage & Profitability & $\begin{array}{l}\text { Intellectual } \\
\text { capital level }\end{array}$ \\
\hline Mean & 0.43 & 20.47 & 0.73 & 7.43 & 0.02 & 2.47 \\
Maximun & 0.80 & 25.10 & 0.96 & 93.87 & 0.18 & 11.17 \\
Minimun & 0.04 & 16.99 & 0.22 & -2.71 & -0.23 & -0.18 \\
St. deviation & 0.19 & 2.05 & 0.17 & 14.62 & 0.07 & 2.06 \\
\hline $\mathbf{n}$ & 45 & 45 & 45 & 45 & 45 & 45 \\
\hline
\end{tabular}

Table 6: Summary descriptive statistics of categorical variables

\begin{tabular}{|c|c|c|c|c|c|c|c|c|c|c|}
\hline & $\begin{array}{l}\text { Type of } \\
\text { auditor } \\
\text { (TA) }\end{array}$ & $\begin{array}{l}\text { Oil \& \& } \\
\text { Gas }\left(I_{1}\right)\end{array}$ & $\begin{array}{l}\text { Basic } \\
\text { Materials } \\
\left(\mathbf{I}_{2}\right) \\
\end{array}$ & $\begin{array}{l}\text { Indust. } \\
\left(\mathbf{I}_{3}\right)\end{array}$ & $\begin{array}{l}\text { Cons. } \\
\text { Goods } \\
\left(\mathbf{I}_{4}\right) \\
\end{array}$ & $\begin{array}{l}\text { Cons. } \\
\text { Services } \\
\left(\mathbf{I}_{\mathbf{5}}\right) \\
\end{array}$ & $\begin{array}{l}\text { Telecom. } \\
\left(\mathbf{I}_{\mathbf{6}}\right)\end{array}$ & \begin{tabular}{|l} 
Utilities \\
$\left(\mathbf{I}_{7}\right)$
\end{tabular} & $\begin{array}{l}\text { Financials } \\
\left(\mathbf{I}_{8}\right)\end{array}$ & $\begin{array}{l}\text { Technology } \\
\text { (I্) }\end{array}$ \\
\hline \multicolumn{11}{|l|}{$i=0$} \\
\hline $\mathrm{N}$ & 18 & 44 & 40 & 32 & 42 & 34 & 43 & 44 & 40 & 41 \\
\hline$\%$ & $40 \%$ & $98 \%$ & $89 \%$ & $71 \%$ & $93 \%$ & $76 \%$ & $96 \%$ & $98 \%$ & $89 \%$ & $91 \%$ \\
\hline \multicolumn{11}{|l|}{$i=1$} \\
\hline $\mathrm{N}$ & 27 & 1 & 5 & 13 & 3 & 11 & 2 & 1 & 5 & 4 \\
\hline$\%$ & $60 \%$ & $2 \%$ & $11 \%$ & $29 \%$ & $7 \%$ & $24 \%$ & $4 \%$ & $2 \%$ & $11 \%$ & $9 \%$ \\
\hline Total & 45 & 45 & 45 & 45 & 45 & 45 & 45 & 45 & 45 & 45 \\
\hline
\end{tabular}

The ICD ranges from 0.04 to 0.8 with a mean of 0.43 and a standard deviation of 0.19 . Leverage and Intellectual Capital Level assume negative values because one of the companies in the sample has negative equity, which is an abnormal situation. This company is not considered in the regression analysis.

60 percent of the companies in the sample utilised the services of the big international audit firms. The 9 dummies for each of the sector sampled are control variables.

\subsection{Analysis of the main results}

Table 7 reports the results of regressing the independent variable on the dependent variables. The F-value for the model is significant at 0.01 level. This suggests that the independent variables considered, when taken together, do affect total ICD. However, this does not mean that each of the independent variables contributes to the explanation of the dependent variables.

The adjusted R2's suggest that approximately $40 \%$ of the variation in the ICD scores between the companies can be explained by the independent variables included in the regression model. Only four of the independent variables are significant: size, type of auditor, I3, and I5. The coefficient of total assets is positive, indicating as hypothesised, that as the value of this 
variable increases so does a company's ICD score.

Table 7: Results of the regression model

\begin{tabular}{|llll|}
\hline Independent variables & Coefficient & t-Statistic & Prob. \\
\hline \hline (Constant) & -0.86 & -1.73 & 0.09 \\
Size & 0.06 & 2.66 & 0.01 \\
Onwnership concentration & 0.18 & 0.90 & 0.38 \\
Profitability & 0.48 & 1.03 & 0.31 \\
Leverage & 0.00 & 1.61 & 0.12 \\
Type of auditor & 0.09 & 1.69 & 0.10 \\
Intellectual capital level & 0.00 & -0.03 & 0.98 \\
I1 & -0.23 & -1.07 & 0.29 \\
I2 & -0.19 & -1.31 & 0.20 \\
I3 & -0.27 & -2.00 & 0.05 \\
I4 & -0.22 & -1.47 & 0.15 \\
I5 & -0.22 & -1.69 & 0.10 \\
I6 & -0.19 & -1.07 & 0.29 \\
I7 & -0.14 & -0.64 & 0.53 \\
I8 & -0.27 & -1.37 & 0.18 \\
\hline \hline R-squared & 0.59 & & \\
Adjusted R-squared & 0.40 & & \\
F-statistic & 3.03 & & \\
\hline
\end{tabular}

Thus, at an aggregated level, the supported research hypotheses in the case of ICD in annual reports are those related to size $(\mathrm{H} 1)$ and type of auditor (H6). The results pertaining to variables I3 and I5 suggest that there are some effects of industry affiliation on ICD.

Consistent with previous studies, size has a positive relationship with ICD. To further investigate the effect of size, the dataset was separated into large and small firms. Firms whose size is equal to or above the median are considered large, while firms that fall below the median are small firms. Results are valid both considering the global sample and considering the small and large companies samples. These results are consistent with the expectations resulting from the theoretical framework proposed and with previous ICD studies (see, for example, Guthrie et al., 2006; Bozzolan et al., 2003; García-Meca et al., 2005; García-Meca and Martínez, 2005; Li et al., 2007; Oliveira et al., 2006; Ousama et al., 2012).

Ownership concentration is not a factor which explains the differences in ICD among companies. This is an unexpected finding. The findings of Oliveira et al. (2006) revealed a significant and negative relationship between these variables. The different period of analysis and the different data collection method probably contributed to this discrepancy. Nonetheless, it is important to note that Portuguese companies present a high degree of ownership concentration. This is shown by the comparison of the descriptive statistics for this 
variable in different studies (Table 8).

Table 8: Comparison of descriptive statistics for ownership concentration in different studies

\begin{tabular}{|llllll|}
\hline Ownership concentration & Country & Mean & Median & Min & Max \\
\hline \hline This study & Portugal & $72.50 \%$ & $77.97 \%$ & $22.23 \%$ & $96.12 \%$ \\
Oliveira et al. (2006) & Portugal & $62.89 \%$ & n.d. & $7.79 \%$ & $99.36 \%$ \\
Firer e Williams (2005) & Singapore & $62.54 \%$ & $57.59 \%$ & n.d. & n.d. \\
Li et al. (2008) & UK & $29.63 \%$ & $26.05 \%$ & $0 \%$ & $79.20 \%$ \\
Whiting and Woodcock (2011) & Australia & $38.42 \%$ & $37.75 \%$ & $11.82 \%$ & $91.60 \%$ \\
\hline \hline
\end{tabular}

The inexistence of a significant relationship may be related to the high levels of ownership concentration in the sample. When there is a high level of ownership concentration, the main shareholders have other ways of obtaining the information they need besides the annual report. Thus, this variable is not significantly related to ICD when the levels of ownership concentration are high.

In this study, no relationship between leverage and ICD is detected. The results obtained are similar to those of Ho and Wong (2001), Oliveira et al. (2006) and Ousama et al. (2012) and Whiting and Woodcock (2011). In the Portuguese case, the inexistence of a significant relationship is probably related to the predominantly bank-oriented financing policies. This is also a characteristic of listed companies' financing policies.

Regarding industry affiliation, only the variables I3 (Industrials) and I5 (Consumer Services) are statistically significant.

The coefficient on TA (type of auditor) is positive and statistically significant, suggesting that companies audited by the Big-4 audit firms disclose more intellectual capital information than companies audited by other audit firms. These results are consistent with the findings of Oliveira et al. (2006).

The non-significant relation between ICD and HV is an unexpected result. The inexistence of a significant relationship must be analysed with caution. Hidden value is a flawed measure of intellectual capital since book values may be understated and market values may be influenced by expectations of investors pertaining to growth potential due to factors other than intellectual capital (Whiting and Miller, 2008). Whiting and Miller (2008) and Brennan (2001) used similar measures (based on the difference between market and book value) and were also unable to find a significant relationship.

\section{Conclusion}

This study analyses some factors which influence ICD by a sample of companies listed on the Portuguese Stock Exchange (Euronext - Lisbon), using a costs/benefits theoretical framework. According to this framework, companies have an incentive to disclose voluntary 
information when the benefits to be derived from additional disclosure are perceived to outweigh the associated costs.

The findings reported in this study are consistent with those obtained in previous studies (Oliveira et al., 2006). Information on external capital is the type of information on IC that more companies disclose in their annual reports. The kind of intellectual information that more companies disclose in their annual reports pertains to management processes, business collaborations, brands, and the profile of workers.

The results reveal that size and type of auditor are significant in explaining ICD by Portuguese listed companies. Larger firms with higher followings by investors and with higher political costs of non-compliance or litigation threat have higher quality disclosures, as expected. Large audit firms have more concern for their reputation and will incite their clients to disclose high quality information.

The other variables analysed (leverage, profitability, ownership concentration, and intellectual capital level) are not significant in explaining ICD by Portuguese listed companies. However, the lack of significant relationships between these variables and ICD is probably related to the particular characteristics of the Portuguese economy, such as the high levels of ownership concentration and the importance of bank finance.

The findings confirm results of previous studies pertaining to the importance of size and type of auditor as factor explaining ICD. In addition, the studies suggest the existence of threshold level of disclosure, above which the benefits (such as lower agency costs, political costs, borrowing costs, and decreased information asymmetry) no longer outweigh the costs associated with disclosure (such as the cost of preparing, disseminating and auditing information, and the costs resulting from disclosure of proprietary information).

We suggest that the lack of a significant relationship between ownership concentration and ICD is probably related to the high levels of ownership concentrations observed in the Portuguese economy. In these situations, major shareholders are more likely to have access to all the relevant information they need to make decisions, and do not need additional disclosures. This suggestion may give birth to new studies in other countries with similar characteristics.

We interpret the findings as a result of the convergence in corporate practices which is promoted by the impact of globalized stock markets and has, as consequence, a seeming lack of importance of general contextual factors in determining disclosure practices of listed companies (Branco and Rodrigues, 2008). Our study thus calls for a review in ICD research to include research on the relative importance of general contextual factors in influencing disclosure practices of listed companies in comparison with non-listed companies and small and medium sized companies.

We believe that this study contributes to research at least in two other ways. First, it adds to the scarce research on ICD by Portuguese companies by providing new empirical data. We believe that our study has several contributions to the literature. We confirm earlier findings on determinants of ICD in Portugal (Oliveira et al., 2006). Second, it extends prior research 
using cost/benefits perspectives.

However, this study also presents several limitations. First, although it is constituted by all the relevant Portuguese listed companies, the sample may be considered small and this may have encumbered the research. Second, there might be content analysis issues associated with the level of subjectivity involved in the coding process and to the use of a very limited content analysis method obviously has implications on the conclusions.

Our research findings have practical implications. Owing to the increasing importance of intangibles and intellectual capital, how these are reported is of interest to a large range of stakeholders (Bozzolan et al., 2006). Our study may help stakeholders in assessing levels of IC in valuing companies. ICD in Portugal is an important part of the movement towards greater accountability of companies. Increased appreciation of the levels of ICD is likely to encourage greater debate over ICD in Portugal.

Several possible extensions of this study, which are not mutually exclusive, may be considered in order to add new insights to the analysis of ICD by companies. One such possible extension is related to the use of more refined content analysis procedures. Another possible extension is an in-depth analysis of categories of ICD, which very likely would involve variations to the theoretical framework proposed. Finally, the use of a larger sample of Portuguese companies (including small and medium sized companies) would be an interesting way of extending the study which would also involve variations to the theoretical framework. We believe that disclosure practices of listed companies are less subject to general contextual factors than those of unlisted companies.

\section{References}

Abeysekera, I. and Guthrie, J. (2005), “An Empirical Investigation of Annual Reporting Trends of Intellectual Capital in Sri Lanka", Critical Perspectives on Accounting, Vol. 16, pp. 151-163.

April, K., Bosma, P. and Deglon, D. (2003), "IC Measurement and Reporting: Establishing a Practice in SA Mining”, Journal of Intellectual Capital, Vol. 4, No. 2, pp. 165-180.

Azizkhani, M., Monroeb, G. S. and Shailer, G. (2010), "The value of Big 4 audits in Australia", Accounting and Finance, Vol. 50, pp. 743-766.

Barako, D. G., Hancock, P. and Izan, H. Y. (2006), "Factors Influencing Voluntary Corporate Disclosure by Kenyan Companies", Corporate Governance: An International Review, Vol. 14, No. 2, pp. 107-125.

Bewley, K. and Li, Y. (2000), "Disclosure of Environmental Information by Canadian Manufacturing Companies: A Voluntary Disclosure Perspective", Advances in Environmental Accounting and Management, Vol. 1, pp. 201-226.

Botosan, C. A. (1997), "Disclosure Level and the Cost of Equity Capital", The Accounting Review, Vol. 72, No. 3, pp. 323-350.

Bozzolan, S., Favotto, F. and Ricceri, F. (2003), "Italian Annual Intellectual Capital 


\section{$\triangle$ Macrothink}

International Journal of Accounting and Financial Reporting ISSN 2162-3082

Disclosure - An Empirical Analysis", Journal of Intellectual Capital, Vol.4, No. 4, pp. 543-558.

Bozzolan, S., O'Regan, P. and Ricceri, F. (2006), "Intellectual capital disclosure (ICD). A comparison of Italy and the UK", Journal of Human Resource Costing and Accounting, Vol. 10 No. 2, 92-113.

Branco, M. C., Delgado, C., Sousa, C. and Sá, M. (2011), "Intellectual capital disclosure media in Portugal", Corporate Communications: an International Journal, Vol. 16, No. 1, pp. $38-52$.

Branco, M. C., Delgado, C., Sá, M. and Sousa, C. (2010), “An analysis of intellectual capital disclosure by Portuguese companies", EuroMed Journal of Business, Vol. 5, No. 3, pp. 258-278.

Branco, M. C. and Rodrigues, L. L. (2008), "Factors influencing social responsibility disclosure by Portuguese companies", Journal of Business Ethics, Vol. 83, No. 4, pp. 685-701.

Brennan, N. (2001), "Reporting Intellectual Capital in Annual Reports: Evidence from Ireland", Accounting, Auditing and Accountability Journal, Vol. 14, No. 4, pp. 423-436.

Brügen, A., Vergauwen, P. and Dao, M. (2009), "Determinants of intellectual capital disclosure: evidence from Australia”, Management Decision, Vol. 47, No. 2, pp. 233-245.

Bukh, N., Nielsen, C., Gormsen, P., and Mouritsen, J., (2005), "Disclosure of Information on Intellectual Capital in Danish IPO Prospectuses", Accounting, Auditing and Accountability Journal, Vol.18, No. 6, pp. 713-732.

Campbell, D. (2000), "Legitimacy Theory or Managerial Reality Construction? Corporate Social Disclosure in Marks and Spencer Plc Corporate Reports, 1969-1997”, Accounting Forum, Vol. 24, No. 1, pp. 80-100.

Cormier, D. and Magnan, M. (2003), "Environmental Reporting Management: a Continental European Perspective", Journal of Accounting and Public Policy, Vol. 22, pp. 43-62.

Depoers, F. (2000), "A Cost-Benefit Study of Voluntary Disclosure: Some Empirical Evidence from French Listed Companies", European Accounting Review, Vol. 9, No. 2, pp. 245-263.

Firer, S. and Williams, S. M. (2005), "Firm ownership structure and intellectual capital disclosures", South African Journal of Accounting Research, Vol. 19, No. 1, pp. 1-18.

García-Meca, E. and Martínez, I. (2005), “Assessing the Quality of Disclosure on Intangibles in the Spanish Capital Market", European Business Review, Vol.17, No. 4, pp. 305-313.

García-Meca, E., Parra, I., Lárran, M. and Martínez, I. (2005), "The Explanatory Factors of Intellectual Capital Disclosure to Financial Analysts", European Accounting Review, Vol. 14, No. 1, pp. 63-94. 


\section{MInstitute Macrothink $_{\text {Int }}$}

International Journal of Accounting and Financial Reporting ISSN 2162-3082

Guthrie, J. and Petty, R. (2000), "Intellectual Capital: Australian Annual Reporting Practices", Journal of Intellectual Capital, Vol.1, No. 3, pp. 241-251.

Guthrie, J., Petty, R. and Ricceri, F. (2006), "The Voluntary Reporting of Intellectual Capital: Comparing Evidence from Hong Kong and Australia", Journal of Intellectual Capital, Vol.7, No. 2, pp. 254-271.

Guthrie, J., Petty, R., Yongvanich, K. and Ricceri, F. (2004), "Using Content Analysis as a Research Method to Inquire into Intellectual Capital Reporting", Journal of Intellectual Capital, Vol. 5, No. 2, pp. 282-293.

Guthrie, J., Ward, L. and Cuganesan, S. (2008), 'Intellectual capital reporting media in an Australian industry', International Journal of Learning and Intellectual Capital, Vol. 5, No. 1, pp.48-62.

Hakim, F. and Omri, M. A. (2010), "Quality of the external auditor, information asymmetry, and bid-ask spread: Case of the listed Tunisian firms", International Journal of Accounting and Information Management, Vol. 18, No. 1, pp. 5-18.

Haniffa, M.R. and Cooke, T.E. (2005), “The Impact of Culture and Governance on Corporate Social Reporting", Journal of Accounting and Public Policy, Vol. 24, pp. 391-430.

Healy, P. and Palepu, K. (1993), “The Effect of Firm's Financial Disclosure Strategies on Stock Prices", Accounting Horizons, Vol.7, No.1, pp. 1-11.

Healy, P., Hutton, A. and Palepu, K. (1999), "Stock Performance and Intermediation Changes Surrounding Sustained Increases in Disclosure", Contemporary Accounting Research, Vol.16, No. 3, pp. 485-520.

Ho, S.S.M. and Wong, K.S. (2001), "A Study of the Relationship between Corporate Governance Structures and the Extent of Voluntary Disclosure", Journal of International Accounting, Auditing and Taxation, Vol.10, No. 2, pp.139-156.

Khlif, H. and Souissi, M. (2010), "The determinants of corporate disclosure: a meta-analysis", International Journal of Accounting and Information Management, Vol. 18, No. 3, pp. 198-219.

Lang, M.H. and Lundholm, R.J. (1993), "Cross-sectional Determinants of Analyst Ratings of Corporate Disclosures”, Journal of Accounting Research, No. 31, pp. 246-271.

Li, J., Pike, R. and Haniffa, R. (2007), "Intellectual Capital Disclosure in Knowledge Rich Firms: The Impact of Market and Corporate Governance Factors", Bradford University School of Management, Working Paper No. 07/06.

Li, J., Pike, R. and Haniffa, R. (2008), "Intellectual capital disclosure and corporate governance structure in UK firms", Accounting and Business Research, Vol. 38, No. 2. pp. 137-159.

Milne, M. and Adler, R. (1999), "Exploring the Reliability of Social and Environmental Disclosures Content Analysis", Accounting, Auditing and Accountability Journal, Vol. 12, No. 
2, pp. 237-256.

Oliveira, L., Rodrigues, L. and Craig, R. (2006), "Firm-specific Determinants of Intangibles Reporting: Evidence from the Portuguese Stock Market", Journal of Human Resource Costing and Accounting, Vol. 10, No. 1, pp. 11-33.

Ousama, A. A., Fatima, A.-H. and Hafiz-Majdi, A. R. (2012), "Determinants of intellectual capital reporting: Evidence from annual reports of Malaysian listed companies", Journal of Accounting in Emerging Economies, Vol. 2, No. 2, pp. 119-139.

Petty, R. and Cuganesan, S. (2005), "Voluntary Disclosure of Intellectual Capital by Hong Kong Companies: Examining Size, Industry and Growth Effects over Time", Australian Accounting Review, Vol. 15, No. 2, pp. 40-50.

Prencipe, A. (2004), "Proprietary Costs and Determinants of Voluntary Segment Disclosure: Evidence from Italian Listed Companies", European Accounting Review, Vol. 13, No. 2, pp. 319-340.

Rashid, A. (2010), "Corporate intellectual capital disclosure in a non-mandatory disclosure regime", presented at the Sixth Asia Pacific Interdisciplinary Research in Accounting Conference, 11-13th July, Sidney, Australia

Rashid, A. A., Ibrahim, M. K., Othman, R. and See, K. F. (2012), "IC disclosures in IPO prospectuses: evidence from Malaysia”, Journal of Intellectual Capital, Vol. 13, No. 1, pp. 57-80.

Schiemann, F., Richter, K. and Günther, T. (2011), "Voluntary disclosure of intellectual capital items in roadshows and investor conferences: an empirical analysis of DAX30-companies", Zeitschrift für Planung \& Unternehmenssteuerung, Vol. 21, pp. 255-275.

Sengupta, P. (1998) “Corporate Disclosure Quality and the Cost of Debt", The Accounting Review, Vol. 73, pp. 459-474.

Sonnier, B.M. (2008), "Intellectual capital disclosure: high-tech versus traditional sector companies”, Journal of Intellectual Capital, Vol. 9, No. 4, pp. 705-722.

Sveiby, K. (1997), The New Organizational Wealth: Managing and Measuring Knowledge Based Assets, Berret-Koehler Pub. Inc., San Francisco.

Souissi, M. and Khlif, H. (2012), "Meta-analytic review of disclosure level and cost of equity capital", International Journal of Accounting and Information Management, Vol. 20, No. 1, pp. 49-62.

Unerman, J. (2000), "Methodological Issues - Reflections on Quantification in Corporate Social Reporting Content Analysis", Accounting, Auditing and Accountability Journal, Vol.13, No. 5, pp. 667-680.

Vergauwen, P. and Alem, F. (2005), “Annual Report IC Disclosures in the Netherlands, France and Germany”, Journal of Intellectual Capital, Vol. 6, No. 1. pp. 89-104. 


\section{Macrothink}

International Journal of Accounting and Financial Reporting

ISSN 2162-3082 2012, Vol. 2, No. 2

Verrecchia, R. (1983), "Discretionary Disclosure”, Journal of Accounting and Economics, Vol. 5, pp. 179-194.

Watts, R. and Zimmerman, J. (1979), "The Demand for and Supply of Accounting Theories: The Market for Excuses", The Accounting Review, Vol. 54, No. 2, pp. 273-305.

Watts, R. and Zimmerman, J. (1979), "The Demand for and Supply of Accounting Theories: The Market for Excuses", The Accounting Review, Vol. 54, No. 2, pp. 273-305.

Whiting, R. H. and Miller, J. (2008), "Voluntary disclosure of intellectual capital in New Zealand annual reports and the «hidden value»", Journal of Human Resource Costing and Accounting, Vol. 12, No. 1, pp. 26-50.

Whiting, R. W. and Woodcock, J. (2011), "Firm characteristics and intellectual capital disclosure by Australian companies", Journal of Human Resource Costing and Accounting, Vol. 15, No. 2, pp. 102-126.

Williams, S. (2001), "Are Intellectual Capital Performance and Disclosure Practices Related?”, Journal of Intellectual Capital, Vol. 2, No. 3, p.p. 192-203.

\section{Copyright Disclaimer}

Copyright reserved by the author(s).

This article is an open-access article distributed under the terms and conditions of the Creative Commons Attribution license (http://creativecommons.org/licenses/by/3.0/). 